\title{
Quantification of urinary 5-hydroxyindoleacetic acid by in-house nitrosonaphthol reaction compared with nitrosonaphthol micro column chromatography and enzyme-linked immunosorbent assay
}

\author{
Quantificação do ácido 5-hidroxi-indolacético urinário por técnica caseira \\ do nitrosonaftol comparada com ensaio de nitrosonaftol em microcoluna de \\ cromatografia e imunoensaio enzimático
}

Joyce Matie Kinoshita da Silva ${ }^{1}$; Rejane Mattar²; Carlos Colaúto ${ }^{3}$; Flair José Carrilho ${ }^{4}$

\begin{abstract}
The aim of this study was to compare the colorimetric "kit" and enzyme-linked immunosorbent assay (ELISA) methods to quantify urinary 5-hydroxyindoleacetic acid through the Goldenberg's technique, exploring the potential of replacing it. 24-hour urine samples were tested by Goldenberg's assay and compared with kits. The agreement was almost perfect for the comparison of Goldenberg's assay with both colorimetric kit, and with ELISA kit, considering $\leq 7.5 \mathrm{mg} / 24 \mathrm{~h}$ normal cutoff value. Therefore, both "kits" would be good alternatives to Goldenberg's technique due to practicality and agreement between values.
\end{abstract}

Key words: 5-hydroxyindoleacetic acid; ELISA; carcinoid tumors; serotonin; nitrosonaphthol.

\section{INTRODUCTION}

Carcinoid tumors are neuroendocrine tumors (NET) that most commonly occur in the small intestine, rectum, appendix and colon of the gastrointestinal tract ${ }^{(6)}$. Quantifying urinary 5-hydroxyindoleacetic acid (5-HIAA), the main metabolite of serotonin, is a useful marker for screening and monitoring carcinoid tumors, and also helps in the differentiation of acute appendicitis from other abdominal pain etiologies ${ }^{(1,4,5)}$.

The 24-hour urine 5-HIAA test can be determined by highperformance liquid chromatography (HPLC), the colorimetric assay proposed by Goldenberg ${ }^{(3)}$ in 1973 that uses nitrosonaphthol and 2-mercaptoethanol, enzyme immunoassay, and gas chromatography-mass spectrometry ${ }^{(1,3,5)}$. The 24-hour urine 5-HIAA test performed with the commercial "kit" is an alternative to laboratories lack of equipment for conducting the HPLC technique, which is most employed ${ }^{(1,4,5)}$.

The colorimetric assay proposed by Goldenberg ${ }^{(3)}$ is faster than the HPLC method, especially for routine analysis for a high number of samples. However, this technique, even with modifications, uses hazardous and volatile compounds. Recently, colorimetric "kit" and enzyme-linked immunosorbent assay (ELISA) methods were developed as substitutes to these laborious techniques. Therefore, the aim of this study was to compare the colorimetric "kit" and ELISA methods for measuring 5-HIAA with Goldenberg's assay.

First submission on 11/11/13; last submission on 16/05/14; accepted for publication on 17/05/14; published on 20/06/14

1. Graduated student (Clinical and Experimental Oncology at Universidade Federal de São Paulo [UNIFESP]); biologist at the Gastroenterology and Hepatology Department at Hospital das Clínicas at Faculdade de Medicina da Universidade de São Paulo (FMUSP).

2. PhD in Science (Microbiology and Immunology at UNIFESP); physician at the Gastroenterology and Hepatology Department at Hospital das Clínicas at FMUSP.

3. Technician in Clinical Pathology at the Gastroenterology and Hepatology Department at Hospital das Clínicas at FMUSP.

4. PhD in Gastroenterology - Medicine School - USP; chairman of the Gastroenterology and Hepatology Department at Hospital das Clínicas at FMUSP. 


\section{METHODS}

This study was approved by the Institutional Ethics Committee (CAPPesq 0392/2009). One group of 40 anonymous 24-hour urine samples that entered the lab for routine 5-HIAA test were performed with Goldenberg's assay ${ }^{(3)}$, denominated as the in-house technique, and compared with the colorimetric "kit" by BioSystems (Barcelona, Spain), which is similar in principle to Goldenberg's assay (spectrophotometric quantification of serotonin metabolites [5-HT] and 5-hydroxytryptophan [5-HTP] by the complex formed from the reaction with 1-nitroso-2-naphthol).

Goldenberg's assay ${ }^{(3)}$ was performed according to technique briefly described: each $50 \mathrm{ml}$ centrifuge tubes was filled with either urine ( $5 \mathrm{ml}$, sample tube), distilled water ( $5 \mathrm{ml}$, blank tube), or $5 \mathrm{ml}$ of 5 -HIAA $(1 \mathrm{mg} / 100 \mathrm{ml})$, standard tube (see description of the preparation below), and $5 \mathrm{ml}$ of $1 \mathrm{M} \mathrm{HCl}, 4 \mathrm{~g}$ of $\mathrm{NaCl}$, and $25 \mathrm{ml}$ of ether. Tubes were shaken for $5 \mathrm{~min}$ and centrifuged for $10 \mathrm{~min}$ at $3000 \mathrm{rpm}$. Ether extract ( $20 \mathrm{ml}$ of the upper phase) was transferred to clean $50 \mathrm{ml}$ centrifuge tubes, with $4 \mathrm{ml}$ of phosphate buffer $(2.59 \mathrm{~g} \mathrm{KH} 2 \mathrm{PO} 4$ and $4.40 \mathrm{~g}$ anhydrous Na2HP0 4 per $500 \mathrm{ml}$ of distilled water, $\mathrm{pH} 7$, and kept at $4^{\circ} \mathrm{C}$ ). Tubes were shaken for 5 min and centrifuged for $10 \mathrm{~min}$ at $3000 \mathrm{rpm}$. The lower aqueous phase $(2 \mathrm{ml})$ was transferred to clean $50 \mathrm{ml}$ centrifuge tubes, avoiding contamination with ether. $0.5 \mathrm{ml}$ of Nitrosonaphthol ( $2 \mathrm{~g} / \mathrm{l}$ of ethanol, stored in amber-colored bottle at $4^{\circ} \mathrm{C}$ ) was added to each tube and $1 \mathrm{ml}$ of nitrous acid $(5 \mathrm{ml}$ of $1 \mathrm{M} \mathrm{HCl}$ and $0.2 \mathrm{ml}$ of $25 \mathrm{~g} / 1$ sodium nitrite) previously prepared and incubated for $5 \mathrm{~min}$ at $37^{\circ} \mathrm{C}$. Mercaptoethanol $\left(250 \mathrm{ml} / \mathrm{l}\right.$, stored at $\left.4^{\circ} \mathrm{C}\right)$ on the volume of $0.2 \mathrm{ml}$ was added and incubated for $20 \mathrm{~min}$ at $37^{\circ} \mathrm{C}$. Ethyl acetate $(5 \mathrm{ml})$ was added, and tubes were vigorously shaken for 60 seconds, and a blue color develops in the lower phase. After the layers were separated, the absorbance of aqueous layer (lower phase) was read against the blank at $590 \mathrm{~nm}$. The calculation was performed as following:

- $\mathrm{mg}$ 5-HIAA $/ 24 \mathrm{~h}=$ absorbance $($ sample)/absorbance (standard) $\times 1 \times$ [24-hour urine volume in $\mathrm{ml} / 100]$.

If the absorbance of the sample was more than three times higher than the absorbance of the standard, the color development was repeated using $0.2 \mathrm{ml}$ of the lower phase of the phosphate extracted with $1.8 \mathrm{ml}$ of phosphate buffer. For calculation, the value obtained with the formula was multiplied by 10 . The time required for the whole analysis is about 2 hours.

The stock 5-HIAA solution standard (Sigma, EUA), $250 \mathrm{mg} / \mathrm{l}$ was prepared in $1 \mathrm{M} \mathrm{HCl}$, stored in amber-colored bottle at $4^{\circ} \mathrm{C}$. The working 5-HIAA standard $(10 \mathrm{mg} / \mathrm{l})$ was prepared diluting $4 \mathrm{ml}$ of the stock standard to $100 \mathrm{ml}$ of thiourea $(1 \mathrm{~g} / \mathrm{l})$, stored in ambercolored bottle, and stable for 2 weeks at $4^{\circ} \mathrm{C}$
According to BioSystems, the colorimetric reaction of the kit is preceded by a chromatographic separation in micro columns; products of the tryptophan metabolism in the sample are retained by a neutral resin. Serotonin and 5-hydroxytryptophan are eluted together first, and then the 5-HIAA. These metabolites are quantified spectrophotometrically through the complex formed by reaction with 1-nitroso-2-naphtol.

Another group of 40 anonymous specimens of 24-hour urine were tested by Goldenberg's assay ${ }^{(3)}$ and an ELISA by IBL International (Hamburg, Germany), which is based on competition between a biotinylated and non-biotinylated antigen for a fixed number of antibody binding sites. Controls and patient samples were diluted, methylated, and ELISA was performed immediately with the supernatant that was stable for 1 hour only.

Measurements were performed using "kits" according to the manufacturers' instructions.

The normal excretion values for Goldenberg's assay were 1-7 $\mathrm{mg} / 2 \mathrm{~h}^{(3)}$, for the colorimetric kit (BioSystems) were 2-6 $\mathrm{mg} / 24 \mathrm{~h}$, and for ELISA kit were $6-10 \mathrm{mg} / 24 \mathrm{~h}$; for this analysis, $\leq 7.5 \mathrm{mg} / 24 \mathrm{~h}$ was considered normal cutoff value.

Statistical analyses were performed using the Kappa index for diagnostic tests measurement and agreement, using SPSS version 15.0 for Windows (Chicago, USA). Urine samples were classified into two groups for the statistical analysis: normal $(\leq 7.5 \mathrm{mg} / 24 \mathrm{~h})$ and higher $(\geq 7.6 \mathrm{mg} / 24 \mathrm{~h})$.

\section{RESULTS}

Forty 24-hour urine samples were analyzed by the tests and separated into two groups: $0.1-7.5 \mathrm{mg} / 24 \mathrm{~h}$ (normal value) and $\geq$ $7.6 \mathrm{mg} / 24 \mathrm{~h}$ (higher value).

When we compared Goldenberg's assay with the colorimetric "kit", only four samples had discordant result; in Goldenberg's assay the values were $4 \mathrm{mg} / 24 \mathrm{~h}, 5.1 \mathrm{mg} / 24 \mathrm{~h}, 7 \mathrm{mg} / 24 \mathrm{~h}$ and $6.9 \mathrm{mg} / 24 \mathrm{~h}$, while by the colorimetric "kit" were $7.8 \mathrm{mg} / 24 \mathrm{~h}, 8.9 \mathrm{mg} / 24 \mathrm{~h}, 7.8 \mathrm{mg} / 24 \mathrm{~h}$ and $8.4 \mathrm{mg} / 24 \mathrm{~h}$, respectively. Sixteen samples that were within the normal range and twenty samples that presented higher values had perfect agreement (Kappa index =0.8), as shown in Figure 1.

When we compared Goldenberg's assay with ELISA, only two samples that were within the normal range by ELISA "kit", $6 \mathrm{mg} / 24 \mathrm{~h}$ and $0.9 \mathrm{mg} / 24 \mathrm{~h}$, had discordant result with Goldenberg's assay with values of $12.9 \mathrm{mg} / 24 \mathrm{~h}$ and $12.3 \mathrm{mg} / 24 \mathrm{~h}$, respectively. Twenty-three samples that were within the normal range and fifteen samples that had higher values had perfect agreement (Kappa index $=0.896)$, as shown in Figure 2. 


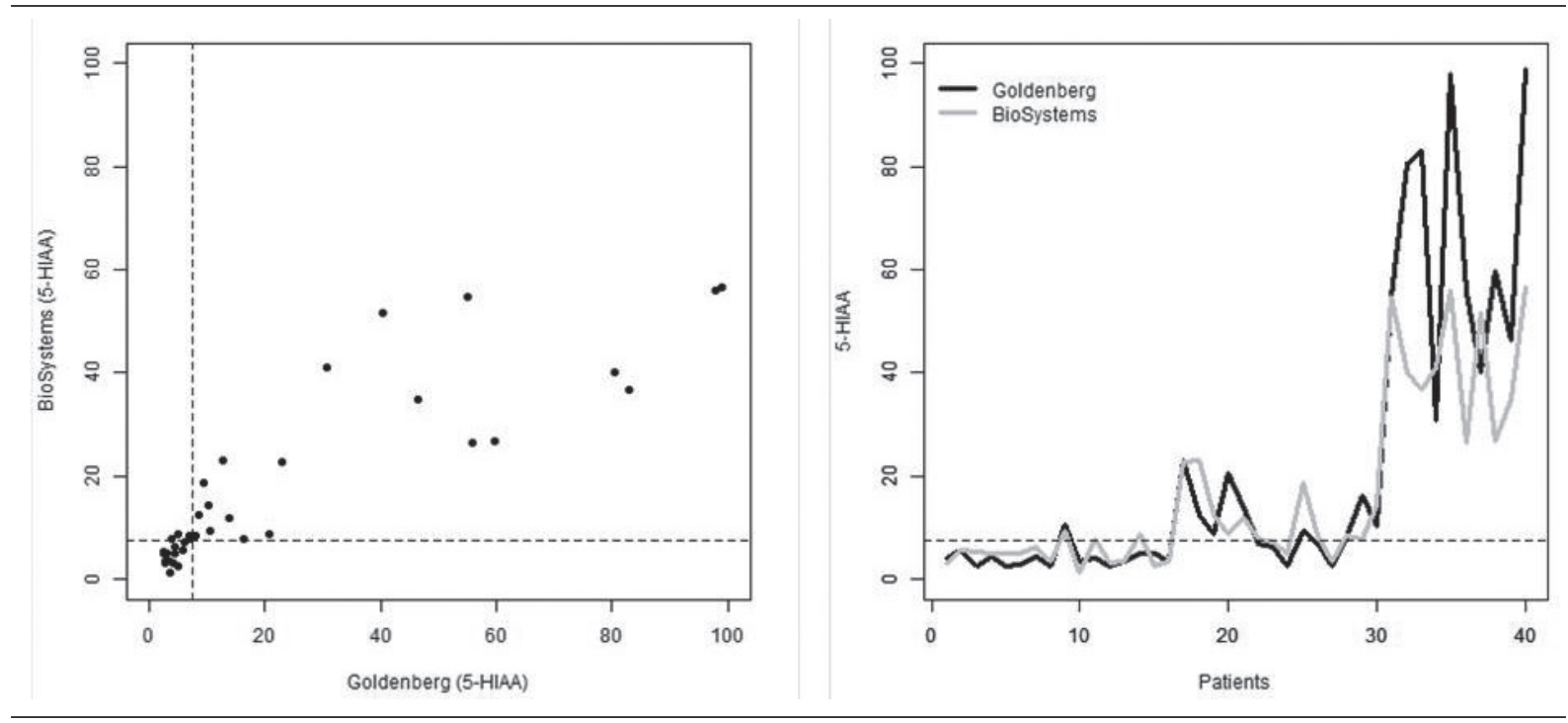

FIGURE 1 - Comparison of 5-HIAA values between Goldenberg's assay (in-house technique) and the BioSystems "kit"

Kappa index $=0.8 ;$ dot-line $=7.5 \mathrm{mg} / 24 \mathrm{~h}$.

5-HIAA: 5-hydroxyindoleacetic acid.
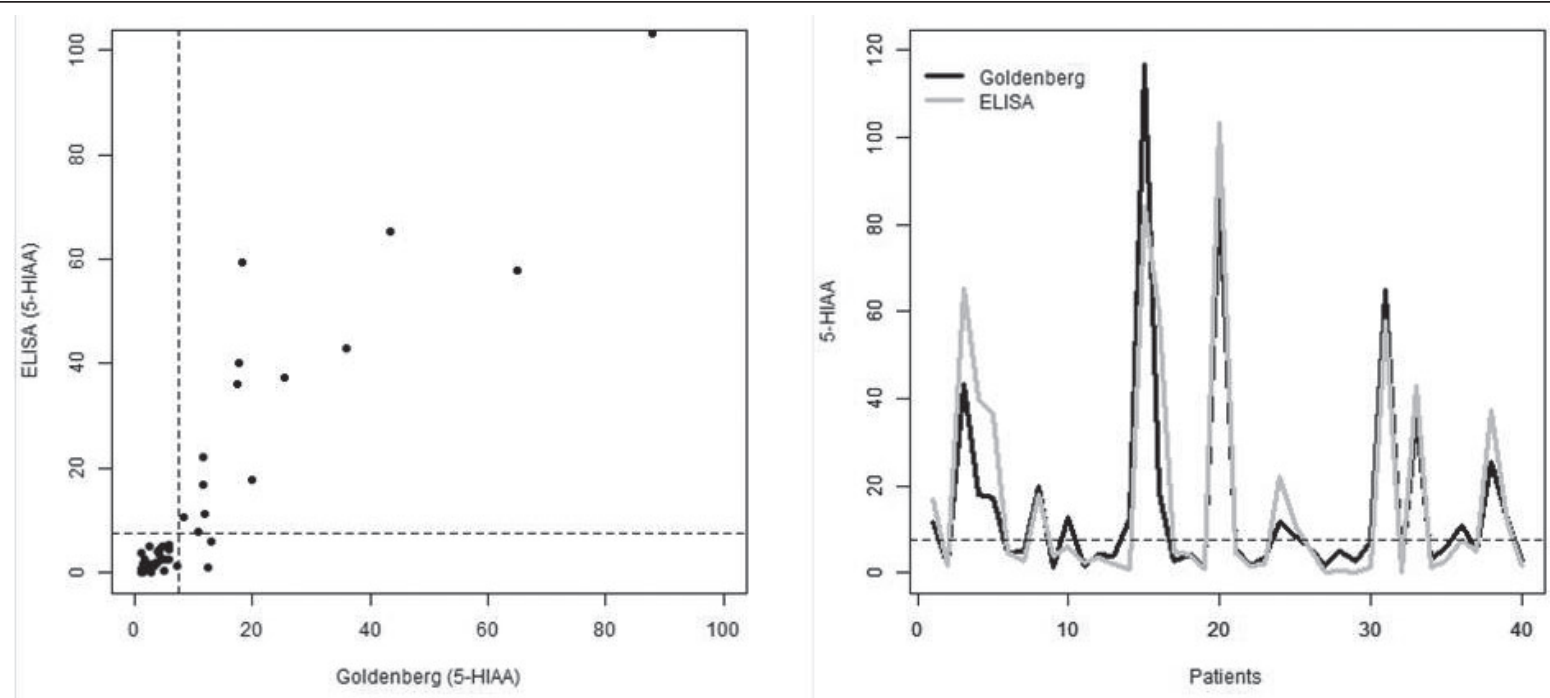

FIGURE 2 - Comparison of 5-HIAA values between Goldenberg's assay (in-house technique) and ELISA "kit"

Kappa index $=0.896 ;$ dot-line $=7.5 \mathrm{mg} / 24 \mathrm{~h}$.

5-HIAA: 5-hydroxyindoleacetic acid; ELISA: enzyme-linked immunosorbent assay.

We did not compare the colorimetric "kit" results with the ELISA results because the techniques were performed at different times.

\section{DISCUSSION}

In general, the incidence of carcinoid tumors in Brazil appears to be increasing; however, the exact incidence is unknown.
Advances in the classification of these tumors have improved treatment, and consequently, patients have longer survivals ${ }^{(2)}$. Thus, urinary measurement of 5-HIAA is widely performed, suggesting the requirement of a more practical, faster, and inexpensive technique to replace Goldenberg's assay, currently routinely used ${ }^{(3)}$. Nonetheless, patients are being followed over the long term according to these values, and a new approach to 5-HIAA measurement must give similar results. 
The comparison of Goldenberg's assay ${ }^{(3)}$ with other techniques is scarce in the literature. Although other techniques, such as HPLC, enzyme immunoassay, and gas chromatographymass spectrometry, may be used, Bolandparvaz et al. ${ }^{(1)}$ suggested the development of easier methods for the accurate and rapid measurement of 5-HIAA. Due to difficulties inherent to most of these methods, we evaluated a colorimetric "kit" (BioSystems) and ELISA (IBL), in comparison to Goldenberg's assay. Both kits were easy and practical but were costly for Public Health Service.

When Goldenberg described this technique in 1973, the main purpose was to improve the specificity and sensitivity of nitrosonaphthol reaction, eliminating the interference of urinary phenolic acids and drug metabolites. For this purpose 2-mercaptoethanol was added to the reaction during the colorimetric assay, and the extraneous colors formed by reactive phenols in urine were blocked by 2-mercaptoethanol. Initially, 5-HIAA was extracted from acidified urine into ether, promoted by the addition of sodium chloride, and recovered from ether into the aqueous phase (the efficiency was maximum with phosphate solution at $\mathrm{pH}$ 7). The next step was the colorimetric assay with nitrosonaphtol and mercaptoethanol, converting it into blue color. Although this technique was performed manually, the comparison with both kits showed almost perfect agreement, confirming the high sensitivity and specificity previously described by Goldenberg ${ }^{(3)}$.

The performance of ELISA kit was better than BioSystems, one possibility is the presence of compounds in urine that did not interfere in ELISA, but could interfere in the colorimetric reaction preceded by chromatographic separation.

\section{CONCLUSION}

Both "kits" would be good alternatives to Goldenberg's technique due to practicality and agreement within values.

\section{CONFLICT OF INTERESTS}

The authors declare no conflict of interests in relation to this paper. The authors declare no conflict of ethics in relation to this paper. The authors alone are responsible for the content and writing of the paper. The authors have neither a commercial nor other associations that might pose a conflict of interest.

\section{AUTHOR CONTRIBUTIONS}

J. M. K. S. and R. M. researched literature and conceived the study. J. M. K. S. and C. C. separated the samples and performed the Goldenberg assays; R. M. and J. M. K. S. performed the colorimetric "kit" experiments, and J. M. K. S. conducted the ELISA. R. M. was responsible for statistical analysis. J. M. K. S. wrote the first draft of the manuscript, and all authors approved the final version.

\section{ACKNOWLEDGMENTS}

The authors thank IBL International and Dr. Nilton Cabrera (DBR Biotech) for supplying the kits for the study and Elsevier for language editing. The authors thank Márcio Augusto Diniz from the Laboratory of Epidemiology and Statistics at Department of Gastroenterology, School of Medicine at Universidade de São Paulo, for his contribution to Figures 1 and 2. This study was supported by Fundação Faculdade de Medicina and Hospital das Clínicas da Faculdade de Medicina da Universidade de São Paulo.

\section{RESUMO}

O objetivo deste estudo foi comparar métodos por kit colorimétrico epor ensaio imunossorvente ligado à enzima (ELISA) para quantificar o ácido 5-hidroxi-indolacético urinário com a técnica de Goldenberg, explorando o potencial de substitui-la. Amostras de urina de 24 horas foram testadas pela técnica de Goldenberg e com os kits. A concordância foi quase perfeita, tanto para a comparação do ensaio de Goldenberg como kit colorimétrico quanto para como kit ELISA, considerando normal o valor de corte de $\leq 7.5 \mathrm{mg} / 24 \mathrm{~h}$. Portanto, ambos os kits seriam boa alternativa para a técnica de Goldenberg devido à praticidade è concordância entre os valores.

Unitermos: ácido 5-bidroxi-indolacético; ELISA; tumores carcinoides; serotonina; nitrosonaftol. 


\section{REFERENCES}

1. BOLANDPARVAZ, S. et al. Urinary 5-hidroxy indole acetic acid as a test for early diagnosis of acute appendicitis. Clin Biochem, v. 37, n. 11, p. $985-9,2004$

2. GANETSKY, A.; BHATT, V. Gastroenteropancreatic neuroendocrine tumors: update on therapeutics. Ann Pharmacother, v. 46, n. 6, p. 851-62, 2012.

3. GOLDENBERG, H. Specific photometric determination of 5hydroxyindoleacetic acid in urine. Clin Chem, v. 19, n. 1, p. 38-44, 1973.
4. HERNANDEZ, R. et al. A prospective clinical trial evaluating urinary 5-hydroxyindoleacetic acid levels in the diagnosis of acute appendicitis. Am J Emerg Med, v. 26, n. 3, p. 282-6, 2008.

5. JANGJ00, A. et al. Is urinary 5-hydroxyindoleacetic acid helpful for early diagnosis of acute appendicitis? Am J Emerg Med, v. 30, n. 4, p. 540-4, 2012.

6. O'TOOLE, D. et al. ENETS consensus guidelines for the standards of care in neuroendocrine tumors: biochemical markers. Neuroendocrinology, v. 90 , n. 2, p. 194-202, 2009.

\section{MAILING ADDRESS}

\section{Rejane Mattar}

Hospital das Clínicas; Divisão de Gastroenterologia e Hepatologia; Av. Dr. Enéas de Carvalho Aguiar 255, $9^{\circ}$ andar, sala 9.159; CEP: 05403-000; São Paulo-SP, Brazil; Phone: +55 (11) 2661-6150; Fax: +55 (11) 2661-7830; e-mail: r.mattar@hc.fm.usp.br. 